\title{
CHANGE OF MORPHOMETRIC AND ALLOMETRIC PATTERNS ON WINGS OF BANDED DEMOISELLE (CALOPTERYX SPLENDENS) MALES \\ IN CASE OF ECOLOGICALLY DIFFERENT WATERCOURSE TYPES
}

\author{
László József Szabó, Csilla Vajda*, Petra Éva Szalay \\ Olga Kis, Margit Miskolczi and György Dévai \\ Department of Hydrobiology, University of Debrecen, H-4032 Debrecen, Egyetem tér 1, Hungary \\ E-mails: szlj55@gmail.com; https://orcid.org/0000-0002-1222-4576 \\ roheryn89@gmail.com; https://orcid.org/0000-0001-8678-0308; *corresponding author \\ pe.szalay@gmail.com; https://orcid.org/0000-0002-8346-2440 \\ kisolgie@gmail.com; https://orcid.org/0000-0001-7737-8587 \\ miskolczi.margit@science.unideb.hu; https://orcid.org/0000-0001-6422-3260 \\ devai.gyorgy@science.unideb.hu; https://orcid.org/0000-0002-9989-9460
}

In nature, dragonfly larvae living in watercourses are exposed to a complex system of environmental influences. Different watercourse types (creeks, brooks, streams, little rivers and medial rivers) are known to provide different conditions for larval development (water depth, flow rate, temperature, oxygen content, substrate type, nutrient supply, etc.). These conditions can vary significantly between watercourse types but can be very similar within types. This work examines the body sizes and wing morphometric characteristics of males of Calopteryx splendens reared from different watercourse types (brook, stream, creek, little river, medial river). Although there were no significant differences in body size depending on watercourse types, significant differences were found in the wing features. We found the greatest number of differences between the individuals reared from streams and creeks and the individuals reared from a stream and medial river. Our results show that the individuals reared from different watercourse types were different on the two wings. The results also suggest significant differences in the number and pattern of allometric features on the wings of individuals reared from different watercourse types.

Key words: damselflies, allometry, wing features variations, NE Hungary

\section{INTRODUCTION}

It is well known that insects living in watercourses are sensitive to different abiotic (CоRвет 1999) and biotic (СоRвет 1999, Мiкоlajewsкi et al. 2005) factors. Among abiotic factors, the abundance of larvae and the composition of species assemblages can be significantly influenced by the hydrolytic conditions of the water body (McLeLLAND et al. 1996), turbidity and conductivity (D'Amico et al. 2004, Stewart \& Downing 2008). The last two factors may affect the choice of the oviposition site (BERNÁth et al. 2002). In these habitats, the influence of temperature and discharge can also be significant on aquatic organisms, and these effects can be very complex and interactive (NAIMAN 
et al. 2002, Petts 2000). Temperature affects the physiology, phenology and seasonality of larvae (Hassall \& Thompson 2008). Moreover, dissolved oxygen affects the behaviour, metabolism and survival of Odonata larvae at a given temperature and pressure (CORBEт 1999). In larvae of odonates the rate of oxygen consumption increases with the rate of waterflow (АмвӥнL 1959, ZAHNER 1959).

In a given watercourse the factors mentioned above act in a complex manner. From this point of view, studies of adults are particularly interesting because individuals have accumulated environmental effects during the larval stages. Minot et al. (2019) pointed out that their study "underscore the importance of taking into account larval growth in order to better understand the adult straits of Odonates". In the species of the genus Calopteryx, the morphology of specimens reflects population response to environmental factors (Svensson et al. 2004, Taylor \& Merriam 1995). In Agria sedule, Stewart and Vodopich (2018) found differences in wing shape and body size among most environments examined. Some studies suggest that habitat type (Outomuro et al. 2013) and habitat fragmentation (TAYLOR \& MERriam 1995) affect adults' wing shape.

The females of the Calopteryx splendens prefer watercourses with dense herbaceous vegetation but avoid the sections with tree coverage along the bank (WARD \& MiLL 2005). The larvae strongly prefer muddy bottoms with silt and detritus, but this is not a necessity (Goodye 2000). Based on many studies, C. splendens specimens are attached to the watercourse they emerged from and migrated only within small distances (StetTMer 1996, WARD \& Mill 2007). Mating and oviposition take place on or close to the water surface (ConвEт 1999). The results of a mark-release-recapture study showed that more than $80 \%$ of the recaptured adults moved within a distance of $100 \mathrm{~m}$ or less, and only $1.3 \%$ of the individuals moved farther than $500 \mathrm{~m}$ (WARD \& MiLL 2007). During our fieldwork, we observed that even though C. splendens has dispersing specimens that fly quickly along the watercourse, a significant number of individuals only populate sections of watercourses with a defined habitus, where they show a strong territorial behaviour. CHAPUT-BARdy et al. (2010) found that the proportion of dispersing individuals is smaller in males than in females. Due to the small migration distance, it can be presumed that male adult specimens developed in the same waterbody at which they were captured. In Hungary, larvae of $C$. splendens can be found in every clear and less polluted watercourse except for the epirithral reaches of highland brooks.

Studies demonstrate differences in body length, wing size, wing shape and wing spot size in different populations (e.g. Mertens et al. 1992, OutomURo et al. 2013, SADEGHI et al. 2009). Such differences can be evolved in a population by phenological ways (HARDERSEN 2010). However, we have little information on the morphometric properties of adults reared from different 
types of watercourses. Larvae developing in ecologically different waterbody types are exposed to different influences, leading to different body structures and morphology of adults (DMitriew et al. 2007).

Morphometric traits correlate with body length, so they are allometric traits (Dubois 1897). If two traits are measured in the same stage, there is static allometry (Schlichting \& Pigliucci 1998, Shingleton et al. 2007). This can result from two processes: autonomic specification of the organ and determination of the final size of the organ based on the total weight (STERN \& EMLEN 1999). In case of static allometry, the equation $Y=b^{*} X^{a}$ describes the correlation between the two body size, which is $\log (\mathrm{Y})=\log (\mathrm{b})+\mathrm{a}^{*} \log (\mathrm{X})$ in logarithmic form. The extents of the allometric effects were examined using the latter equation. The'a' (gradient) is the allometric coefficient (Huxley 1924, SHea 1985). Very little information about the regulation of static allometry is available, but this mechanism is a basic developmental process (SHINGLETon et al. 2007).

Static allometry can be well examined on organisms with discrete stages, such as insects (KLingenberg \& Zimmermann 1992). In the case of insects, the allometric changes occur after larvae have finished feeding. Imaginal tissues in holometabolous insects start growing in the stage of pupa (WiLliams 1980). By hemimetabolous insects (mayflies, damselflies), the process is different. In an Australian mayfly, the allometric changes do not occur in the same larval stage but at the end of the nymphal stage (CAMPBELL 1991).

SACCHI and HARDERSEN (2012) found different allometries between damselflies (Zygoptera) and dragonflies (Anisoptera) and also among Zygoptera families.

It appears that the allometric traits are not constant. Variation in growth is also affected by genetic differences among specimens, differences among habitats and the interaction of these two factors (SHINGLETon et al. 2007). In addition, Horenstein et al. (2010) pointed out that the environment can significantly affect the allometric pattern and body size.

Our observations also suggested that the size and shape of the wings, particularly the wing spot of males, vary in great detail. However, the individuals from the same waterbody are alike and can be separated from individuals from other populations.

Based on the above, the following questions were asked: are there differences in (i) body length or (ii) wing features, and (iii) allometric features and allometric patterns of the individuals reared from different ecological watercourse types?

\section{MATERIAL AND METHODS}

Five male adults were collected from 45 watercourses in NE Hungary with an insect net. The total number of male specimens was 225 . The watercourses were classified into 5 
types: brook, stream, creek, little river, medial river, according to DÉvaI (1976), LAJTER et al. (2010), DÉvar et al. (2001). These types are different in appearance (Fig. 1) and in several characteristics (Table 1), ensuring different conditions for the larvae to develop. Among the main characteristics listed in Table 1, the following watercourse characteristics may affect the development and morphology of larvae: geographical position, flow velocity, substrate type and debris accumulation (see Introduction). The specimens were collected between 27 May and 12 August 2012. The result of the two-way NPMANOVA showed that both the time (month) and watercourse type had a significant effect on the characteristics of the wing. Therefore, to exclude the effect of time, further studies were performed only on the individuals collected in June. In this month, individuals were collected from every type of watercourse. As a result, the number of water bodies (populations) decreased to 29 and was distributed as follows: 3 creeks, 5 brooks, 11 streams, 9 little rivers and 3 medial rivers. Based on the above, the number of specimens included in the comparative study was 155. The number of specimens from each watercourse type was as follows: creeks: 15 specimens, brooks: 25 specimens, streams: 55 specimens, little rivers: 45 specimens, medial rivers: 15 specimens.

Specimens were kept in ethanol $(70 \mathrm{~V} / \mathrm{V} \%)$ till analysis. Measurements were taken with a digital calliper (to the nearest $0.01 \mathrm{~mm}$ ) in case of total body length and Image Tool software 7 in case of wing traits. For the measurements in Image Tool the right fore and hind wings were cut off, and digital photos were taken with an Olympus SZX 16 microscope. 12 traits were measured on the wing: 7 were related to the size and shape of the whole wing and 5 to the size and position of the wing spot (Figs 2A, B).

The nomenclature of the wing venation was based on Dumont (1991), and the distances were measured between the landmarks of SADEGHI et al. (2009). The wing features were the distances between the given landmarks (Table 2). Since the edge of the wing spot is not sharp, the $\mathrm{X}$ and $\mathrm{Y}$ points are marked where $50 \%$ of the cell above the vein is pigmented.

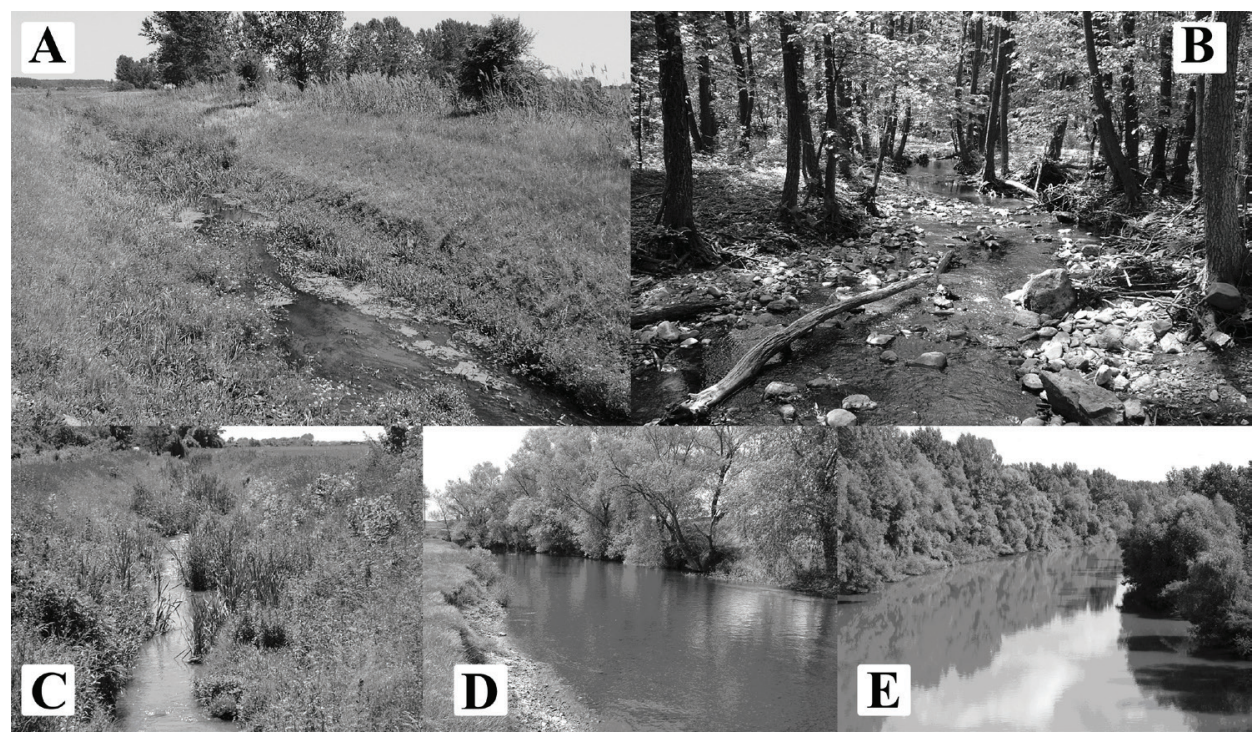

Fig. 1. The typical appearance of watercourse types in Northeast Hungary $(A=$ creek, $B=$ brook, $\mathrm{C}=$ stream, $\mathrm{D}=$ little river, $\mathrm{E}=$ medial river). (Photo: Miskolczi, M.) 


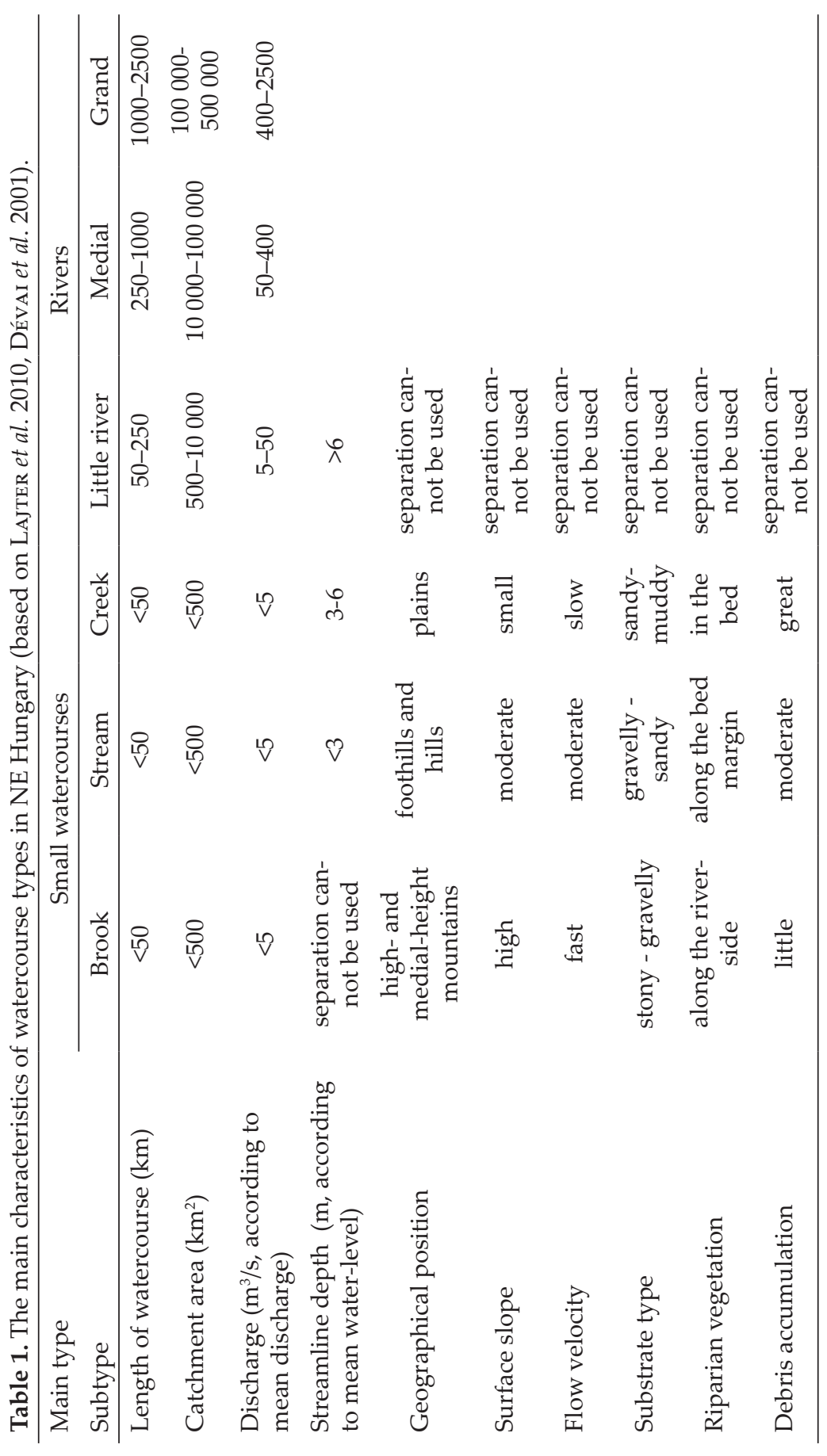


The watercourse types were compared with PCA separately on both wings for populations. The fore and hind wings were compared with the Mantel test and PCA (for all individuals). Since there were differences in magnitude between the values measured on the wings, the raw data were standardised with the range before applying multivariate methods. This means that all data were divided with the range of the watercourse type to retain variability (measured via standard deviation) and set up a range for all variables equal to 1 (Jajuga \& WALESIAK 2000).

Normal distribution of raw data of body length and wing features was examined with the Shapiro \& Wilk test, and the homogeneity of variances was tested by the Levene test. The watercourse types were compared with one-way ANOVA and Tukey post hoc tests (normal distributions), or Kruskal \& Wallis and Mann \& Whitney tests (non-normal distributions).

For the investigation of wing traits allometry, the raw data were log10-transformed for the regression analyses. Similarly to SACCHI and HARDERSEN's (2012) study, the allometric slopes for wing traits were calculated with the standardised major axis regression (SMA). We preferred this method over ordinary least square regression (OLS), because when the independent variable has error variance, the SMA, unlike OLS, does not underestimate slope (SACCHI \& HARDERSEN 2012, WARTon et al. 2006). We ran the SMA for all features of each watercourse type and tested slope differences from 1 by r-statistic. When the correlation was not significant, r-statistics were not performed. This procedure was carried

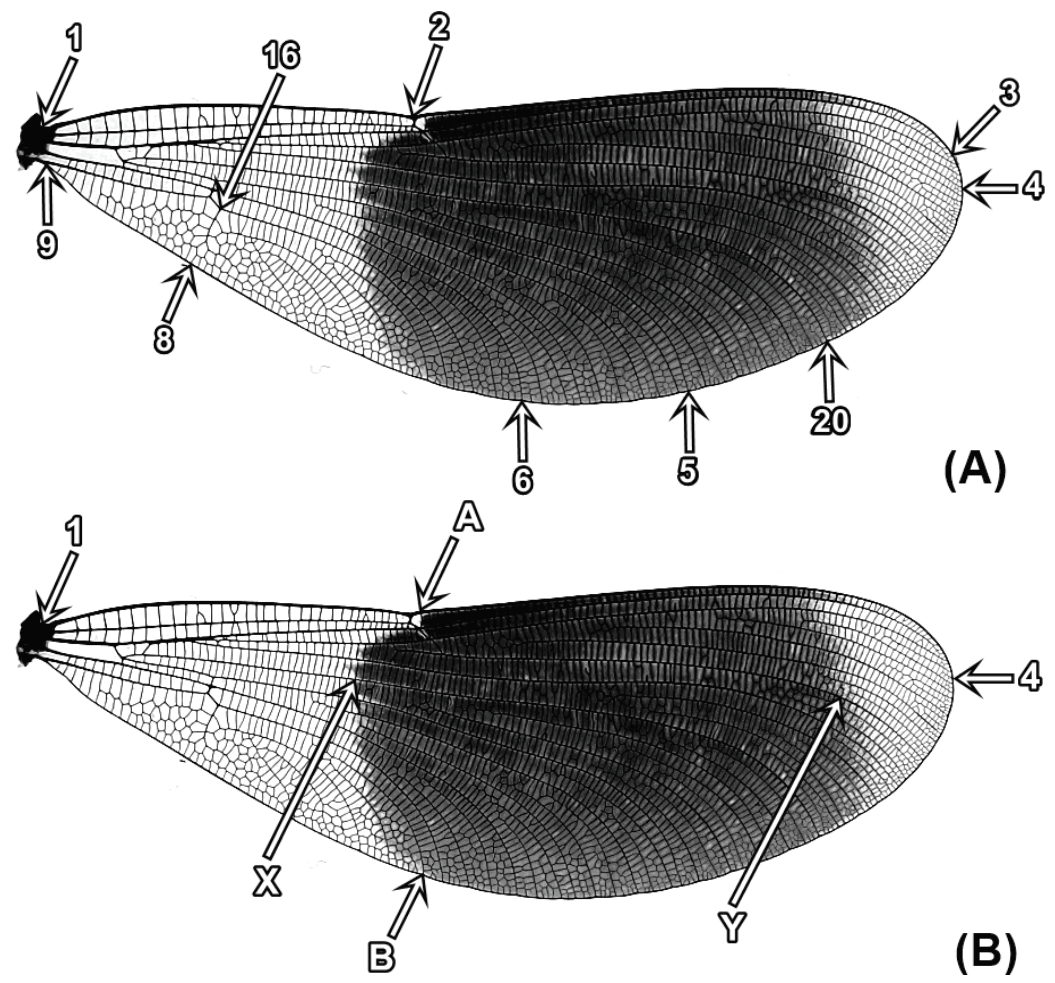

Fig. 2. Measuring points on the right fore wing of Calopteryx splendens males $(\mathrm{A}=$ landmarks related to size and shape measurements, $\mathrm{B}=$ landmarks related to measurements on the wing spot) based on the work of SADEGH et al. (2009) 
Table 2. Differences among watercourse types by features (bold: significant differences).

\begin{tabular}{|c|c|c|c|c|c|c|c|c|}
\hline \multirow{3}{*}{$\begin{array}{l}\text { Fea- } \\
\text { ture }\end{array}$} & \multicolumn{4}{|c|}{ Fore wing } & \multicolumn{4}{|c|}{ Hind wing } \\
\hline & \multicolumn{2}{|c|}{ one-way ANOVA } & \multicolumn{2}{|c|}{ Kruskal-Wallis test } & \multicolumn{2}{|c|}{ one-way ANOVA } & \multicolumn{2}{|c|}{ Kruskal-Wallis test } \\
\hline & $\mathrm{F}$ & $\mathrm{p}$ & $\mathrm{Chi}^{2}$ & $\mathrm{p}$ & $\mathrm{F}$ & $\mathrm{p}$ & $\mathrm{Chi}^{2}$ & $\mathrm{p}$ \\
\hline $1-2$ & & & 23.89 & $<0.0001$ & & & 23.56 & $<0.0001$ \\
\hline $2-3$ & 2.487 & 0.0459 & & & 2.509 & 0.0443 & & \\
\hline $1-4$ & & & 15.38 & 0.004 & 4.089 & 0.0036 & & \\
\hline $2-6$ & & & 10.79 & 0.029 & 3.976 & 0.0043 & & \\
\hline $9-16$ & & & 15.37 & 0.004 & 3.344 & 0.0118 & & \\
\hline $16-8$ & & & 25.70 & $<0.0001$ & 3.543 & 0.0086 & & \\
\hline $9-8$ & & & 10.50 & 0.0327 & & & 14.22 & 0.0066 \\
\hline $1-X$ & 2.189 & 0.0729 & & & 1.500 & 0.2051 & & \\
\hline$X-Y$ & 1.551 & 0.1905 & & & 1.036 & 0.3907 & & \\
\hline $\mathrm{Y}-4$ & 1.925 & 0.1091 & & & & & 4.64 & 0.3257 \\
\hline $1-\mathrm{A}$ & 4.796 & 0.0011 & & & & & 15.40 & 0.0039 \\
\hline 1-B & 3.782 & 0.0058 & & & & & 15.73 & 0.0034 \\
\hline
\end{tabular}

out in both wings. The differences of distribution of allometric traits among watercourse types were analysed by Fisher's exact test (fore and hind wing separately).

The statistical analyses were performed using Microsoft Excel 2003, Past 2.16 software (HAMmer et al. 2001) and smart (WARTON et al. 2012) package in software R (ver. 2.13.1, R Core TeAm 2018).

\section{RESULTS}

In the first step, morphometric measurements were performed on all individuals. The results of the two-way NPMANOVA performed on the data showed that both the watercourse type $(\mathrm{F}=2.23, \mathrm{p}=0.0001)$ and the time (month) $(\mathrm{F}=2.75, \mathrm{p}=0.0001)$ had a significant effect on the morphometric characteristics (but the interaction was not significant). Therefore, in the further analyses, we used only the specimens caught in June.

In all ecologically different watercourse types the average body length values showed normal distribution (Shapiro \& Wilk $\mathrm{W}=0.940-0.974 ; \mathrm{p}=$ $0.120-0.701)$. Moreover, for each type, the differences in total body length of the individuals and their means of body lengths were very similar (the means: creeks: $47.49 \mathrm{~mm}$; brooks $46.83 \mathrm{~mm}$; streams: $47.05 \mathrm{~mm}$, little rivers: $47.55 \mathrm{~mm}$; medial rivers: $47.95 \mathrm{~mm}$ ) (Fig. 3), and there were no significant differences among watercourse types (ANOVA F $=1.79 ; \mathrm{p}=0.135$ ).

In contrast, the one-way ANOVAs and Kruskal \& Wallis tests for the morphometric features of the wing showed significant differences in most of the cases on both wings (Table 2). Only three characteristics connected to the 
patch's position (1-X, X-Y and Y-4) showed no significant differences among watercourse types. In investigating the differences between watercourse types pairwise (Table 3), the same three characteristics (1-X, X-Y and Y-4) and one feature (2-3) of the whole wing measurements showed no significant differences in any pairings. The most significant differences (6 out of 10 pairings) were in features 1-2 on both wings and features 9-16, 1-4, and 16-8 on the fore wing, and 9-8 on the hind wing (Table 3 ). In total, the features of the fore wing distinguished significantly more pairings of watercourses (38) than of the hind wing (26).

The creeks, streams and medial rivers showed the highest number of significant differences with other watercourses (Table 4). Interestingly there were only 2 features that differed significantly between the creeks and medial rivers, while the greatest number of differences were between the stream and the creek (fore wing: 9, hind wing: 7 features), and between the stream and the medial river (fore wing: 7: hind wing: 7) (Table 4). It is also notable that no or only one feature differed significantly between brook, stream, and little river.

According to the PCA based on the features of the fore wing (Fig. 4), the first two principal components explained $89.28 \%$ of total variances (75.11 and $14.17 \%)$. The streams and medial rivers were separated from each other along with the first principal component. This separation was mainly caused by features 1-2 and 16-8. The other three types were separated along with the second principal component. The separation of brooks is mainly caused by features 9-8, 9-16 and 2-6, and the separation of creeks by features 1-X, 1-B and 2-3.

PCA performed for the features of the hind wing (Fig. 4) showed that the first two principal components explained $87.90 \%$ of total variances (77.85 and $10.05 \%)$. Unlike in the fore wing, the separation between streams and medial

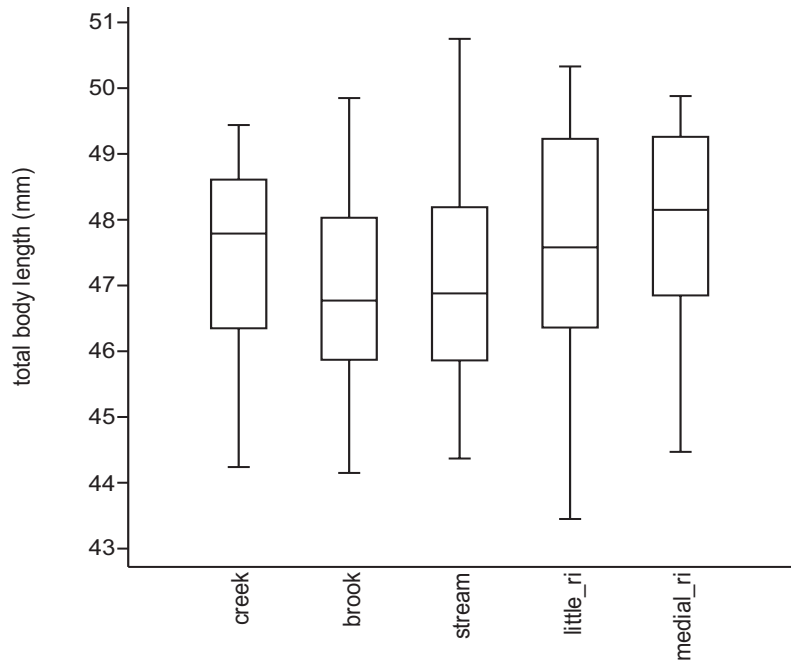

Fig. 3. Boxplot of total body lengths at different watercourse types 

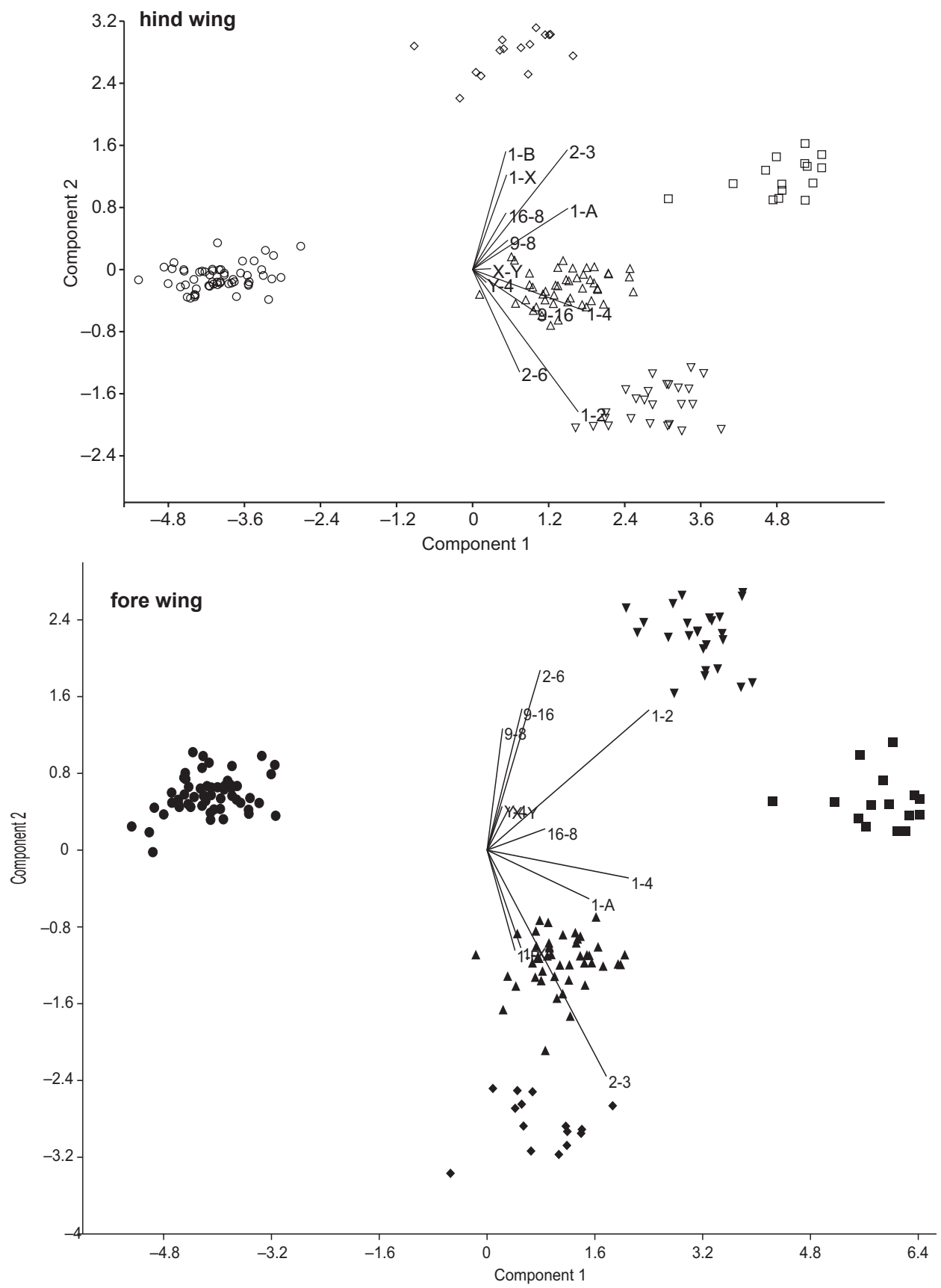

Fig. 4. Results of PCAs (fore wing: 1 . component $=75.11 \%$, 2 component $=14.17 \%$; hind wing: 1 . component $=77,85 \%$, 2 . component $=10,05 \%)$. Symbols: $\bullet=$ creek, $\boldsymbol{\nabla}=$ brook, $\bullet=$ stream, $\mathbf{\Delta}=$ little river, $\mathbf{\square}=$ medial river 
Table 3. The number of significantly different pairings between watercourse types by feature (max. 10 pairs).

\begin{tabular}{lcccccccccccc}
\hline & \multicolumn{11}{c}{ Feature } \\
\cline { 2 - 14 } & $1-2$ & $2-3$ & $1-4$ & $2-6$ & $9-16$ & $16-8$ & $9-8$ & $1-X$ & $X-Y$ & $Y-4$ & $1-A$ & $1-B$ \\
\hline Fore wing & 6 & 0 & 5 & 2 & 6 & 5 & 3 & 1 & 1 & 1 & 4 & 4 \\
Hind wing & 6 & 0 & 2 & 2 & 2 & 2 & 5 & 0 & 0 & 0 & 4 & 3 \\
\hline
\end{tabular}

Table 4. The number of significantly different features between watercourse types (max. 12).

\begin{tabular}{l|lccccc}
\hline \multicolumn{1}{l}{} & \multicolumn{6}{c}{ fore wing } \\
\hline \multirow{3}{*}{$\begin{array}{l}\text { type } \\
\text { hind }\end{array}$ wing } & creek & brook & stream & little river & medial river \\
\cline { 2 - 6 } & brook & 3 & 3 & 9 & 5 & 2 \\
& stream & 7 & 0 & 1 & 0 & 4 \\
& little river & 3 & 0 & 0 & 1 & 7 \\
& medial river & 0 & 3 & 7 & 2 & 4 \\
\hline
\end{tabular}

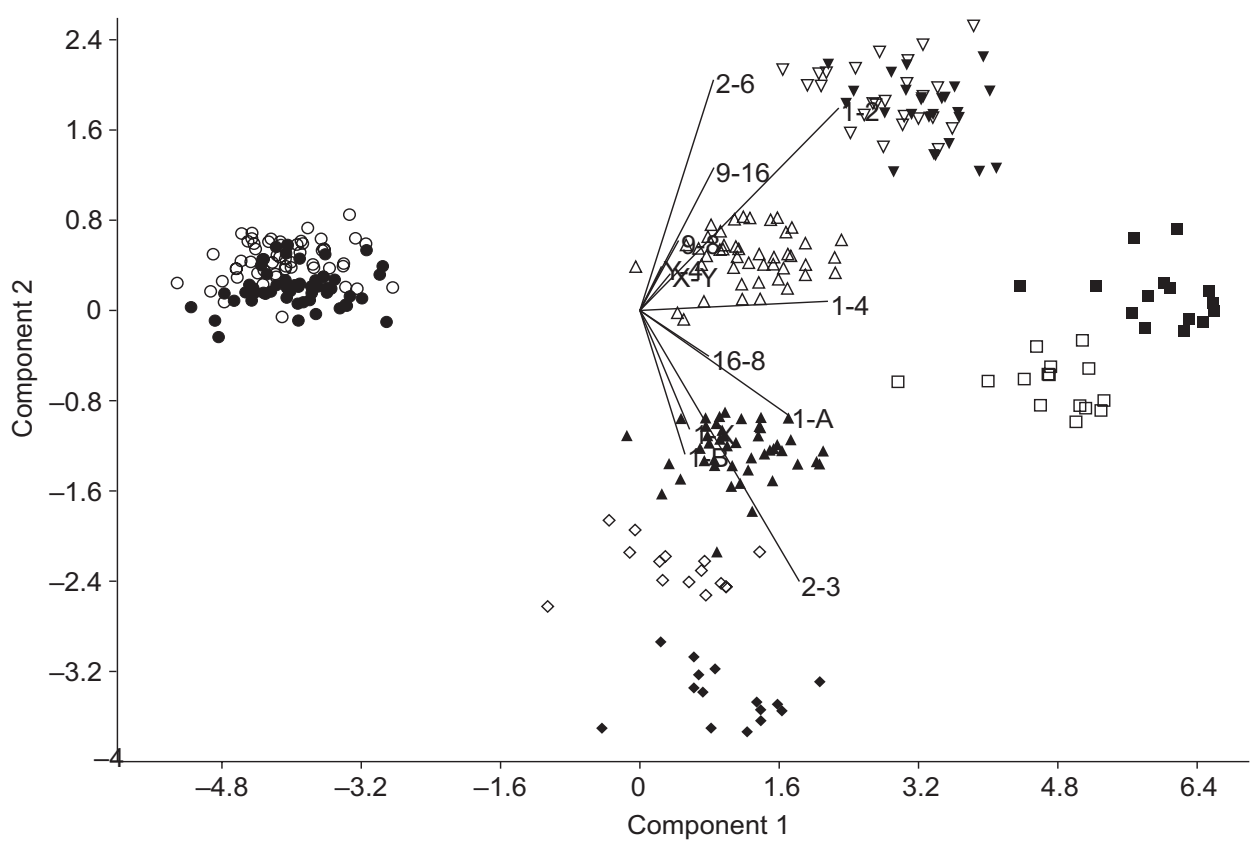

Fig. 5. PCA with watercourse type, for fore and hind wing (1. component $=77.66 \%$; 2 . component $=11.70 \%$ ) (filled symbols: fore wing, empty symbols: hind wing). Symbols: $\boldsymbol{\nabla}$ = creek, $\boldsymbol{\nabla}=$ brook, $\bullet=$ stream, $\boldsymbol{\Delta}=$ little river, $\boldsymbol{\nabla}=$ medial river 
rivers is caused by features $2-3, \mathrm{X}-\mathrm{Y}$ and $16-8$. Along with the second principal component, the separation of brooks and little rivers was caused by features 1-2, 1-4 and 9-16 and the separation of creeks by features 1-X, 1-B and 16-8.

The results of the Mantel test showed that there were close correlations between the features of the two wings $(R=0.979, p=0.0002)$. However, the result of PCAs performed on individuals differed between watercourse types (Fig. 5). For streams and brooks, the point clouds of fore wings and hind wings were completely overlapping. In contrast, these point clouds were slightly different in the creek and the medial rivers and significantly different for the little rivers.

The results of standardised major axis regression (Table 5) showed significant differences in the number of allometric traits and the type of allometry among watercourse types on both wings (Fisher's exact test: fore wing $p$ $<0.0001$, hind wing $\mathrm{p}=0.0012$ ) (Fig. 6).

The number and proportion of allometric features were examined for all individuals. In this case, the total number of cases for all characters was 60 (12 features $\times 5$ types $=60$ ), for features related to the shape and size of the whole wing was 35 ( 7 features $\times 5$ types $=35$ ), and for features related to the shape and size of the wing, spot was 25 ( 5 features $\times 5$ types $=25$ ). Thus, allometric features exceeded $50 \%$ of all features in the first four types of watercourse types (fore wing: $34,56.66 \%$; hind wing: $40,66.67 \%$ ). In the case of features related to the shape of the whole wing, these values are much higher (fore wing: $23,65.71 \%$; hind wing: $28.80 \%$ ). In contrast, the proportion of allometric features related to the shape and size of the wing spot is much smaller (fore wing: $11.44 \%$; hind wing: $12.48 \%$ ).

The allometric pattern on the two wings was very similar in all watercourse types, except the brooks, where three features (9-16, 9-8 and 8-16) differed significantly between wings.

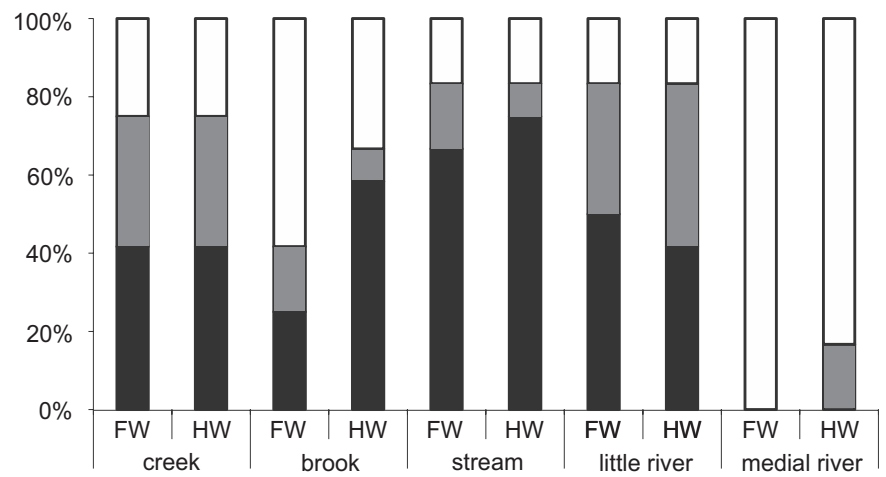

Fig. 6. Patterns of allometric features at different watercourse types. White bars = no allometry, grey bars = isoallometry, black bars = hyperallometry 
Table 5. Results of standardised major axis regressions (bold: isoallometry, bold + gray: hyperallometry).

\begin{tabular}{|c|c|c|c|c|c|c|c|c|c|c|}
\hline \multirow[b]{3}{*}{ y } & \multicolumn{5}{|c|}{ Fore wing } & \multicolumn{5}{|c|}{ Hind wing } \\
\hline & \multicolumn{2}{|c|}{ correlation } & \multicolumn{3}{|c|}{ H0 - slope=1 } & \multicolumn{2}{|c|}{ correlation } & \multicolumn{3}{|c|}{ H0 - slope=1 } \\
\hline & $\mathrm{R}^{2}$ & $\mathrm{p}$ & $\mathrm{r}$ & df & $\mathrm{p}$ & $\mathrm{R}^{2}$ & $\mathrm{p}$ & $\mathrm{r}$ & df & $\mathrm{p}$ \\
\hline \multicolumn{11}{|c|}{ Creek } \\
\hline $1-2$ & 0.597 & 0.0007 & 0.304 & 13 & 0.2715 & 0.485 & 0.0039 & 0.344 & 13 & 0.2093 \\
\hline $2-3$ & 0.444 & 0.0067 & 0.504 & 13 & 0.0556 & 0.337 & 0.0233 & 0.462 & 13 & 0.0831 \\
\hline $1-4$ & 0.534 & 0.002 & 0.321 & 13 & 0.2439 & 0.420 & 0.0089 & 0.474 & 13 & 0.0746 \\
\hline $2-6$ & 0.746 & $<0.0001$ & 0.899 & 13 & $<0.0001$ & 0.440 & 0.007 & 0.616 & 13 & 0.0145 \\
\hline $9-16$ & 0.612 & 0.0006 & 0.800 & 13 & 0.0003 & 0.816 & $<0.0001$ & 0.898 & 13 & $<0.0001$ \\
\hline $16-8$ & 0.673 & 0.0002 & 0.864 & 13 & $<0.0001$ & 0.782 & $<0.0001$ & 0.922 & 13 & $<0.0001$ \\
\hline $9-8$ & 0.377 & 0.0149 & 0.795 & 13 & 0.0004 & 0.620 & 0.0005 & 0.887 & 13 & $<0.0001$ \\
\hline $1-A$ & 0.416 & 0.0094 & 0.379 & 13 & 0.1642 & 0.234 & 0.068 & 0.446 & 13 & 0.0956 \\
\hline 1-B & 0.150 & 0.1537 & & & & 0.309 & 0.0313 & 0.629 & 13 & 0.012 \\
\hline $1-X$ & 0.022 & 0.599 & & & & 0.066 & 0.3567 & & & \\
\hline$X-Y$ & 0.423 & 0.0087 & 0.761 & 13 & 0.001 & 0.147 & 0.1582 & & & \\
\hline Y-4 & 0.001 & 0.9364 & & & & 0.073 & 0.3314 & & & \\
\hline \multicolumn{11}{|c|}{ Brook } \\
\hline $1-2$ & 0.395 & 0.0008 & 0.104 & 23 & 0.6212 & 0.351 & 0.0018 & 0.106 & 23 & 0.615 \\
\hline $2-3$ & 0.055 & 0.2603 & & & & 0.047 & 0.2993 & & & \\
\hline $1-4$ & 0.507 & $<0.0001$ & 0.456 & 23 & 0.022 & 0.451 & 0.0002 & 0.498 & 23 & 0.0113 \\
\hline $2-6$ & 0.036 & 0.3671 & & & & & & & & \\
\hline $9-16$ & 0.042 & 0.3269 & & & & 0.061 & 0.2337 & 0.406 & 23 & 0.0443 \\
\hline $16-8$ & 0.038 & 0.3502 & & & & 0.267 & 0.0082 & 0.856 & 23 & $<0.0001$ \\
\hline $9-8$ & 0.141 & 0.0645 & & & & 0.061 & 0.2328 & 0.729 & 23 & $<0.0001$ \\
\hline $1-A$ & 0.265 & 0.0085 & 0.354 & 23 & 0.0829 & 0.204 & 0.0234 & 0.453 & 23 & 0.023 \\
\hline 1-B & 0.433 & 0.0004 & 0.890 & 23 & $<0.0001$ & 0.370 & 0.0013 & 0.842 & 23 & $<0.0001$ \\
\hline $1-X$ & 0.389 & 0.0009 & 0.922 & 23 & $<0.0001$ & 0.267 & 0.0082 & 0.856 & 23 & $<0.0001$ \\
\hline$X-Y$ & 0.058 & 0.2464 & & & & 0.000 & 0.9393 & & & \\
\hline Y-4 & 0.125 & 0.0832 & & & & 0.131 & 0.0756 & & & \\
\hline \multicolumn{11}{|c|}{ Stream } \\
\hline $1-2$ & 0.621 & $<0.0001$ & 0.201 & 48 & 0.1613 & 0.653 & $<0.0001$ & 0.117 & 53 & 0.3962 \\
\hline $2-3$ & 0.399 & $<0.0001$ & 0.552 & 48 & $<0.0001$ & 0.487 & $<0.0001$ & 0.470 & 53 & 0.0003 \\
\hline $1-4$ & 0.486 & $<0.0001$ & 0.237 & 48 & 0.0982 & 0.473 & $<0.0001$ & 0.209 & 53 & 0.1252 \\
\hline $2-6$ & 0.230 & 0.0004 & 0.446 & 48 & 0.0012 & 0.381 & $<0.0001$ & 0.466 & 53 & 0.0003 \\
\hline $9-16$ & 0.218 & 0.0006 & 0.475 & 48 & 0.0005 & 0.439 & $<0.0001$ & 0.526 & 53 & $<0.0001$ \\
\hline
\end{tabular}


Table 5 (continued)

\begin{tabular}{|c|c|c|c|c|c|c|c|c|c|c|}
\hline \multirow[b]{3}{*}{$\mathrm{y}$} & \multicolumn{5}{|c|}{ Fore wing } & \multicolumn{5}{|c|}{ Hind wing } \\
\hline & \multicolumn{2}{|c|}{ correlation } & \multicolumn{3}{|c|}{ H0 - slope $=1$} & \multicolumn{2}{|c|}{ correlation } & \multicolumn{3}{|c|}{ H0 - slope $=1$} \\
\hline & $\mathrm{R}^{2}$ & $\mathrm{p}$ & $\mathrm{r}$ & $\mathrm{df}$ & $\mathrm{p}$ & $\mathrm{R}^{2}$ & $\mathrm{p}$ & $\mathrm{r}$ & $\mathrm{df}$ & $\mathrm{p}$ \\
\hline \multicolumn{11}{|c|}{ Stream } \\
\hline $16-8$ & 0.146 & 0.0061 & 0.523 & 48 & 0.0061 & 0.428 & $<0.0001$ & 0.543 & 53 & $<0.0001$ \\
\hline $9-8$ & 0.097 & 0.0281 & 0.666 & 48 & 0.0281 & 0.291 & $<0.0001$ & 0.776 & 53 & $<0.0001$ \\
\hline $1-\mathrm{A}$ & 0.429 & $<0.0001$ & 0.608 & 48 & $<0.0001$ & 0.481 & $<0.0001$ & 0.681 & 53 & $<0.0001$ \\
\hline 1-B & 0.370 & $<0.0001$ & 0.809 & 48 & $<0.0001$ & 0.353 & $<0.0001$ & 0.717 & 53 & $<0.0001$ \\
\hline $1-X$ & 0.244 & 0.0003 & 0.877 & 48 & $<0.0001$ & 0.278 & $<0.0001$ & 0.800 & 53 & $<0.0001$ \\
\hline$X-Y$ & 0.055 & 0.1016 & & & & 0.076 & 0.041 & 0.472 & 53 & 0.0003 \\
\hline Y-4 & 0.028 & 0.2488 & & & & 0.063 & 0.065 & & & \\
\hline \multicolumn{11}{|c|}{ Little river } \\
\hline $1-2$ & 0.419 & $<0.0001$ & -0.309 & 43 & 0.0386 & 0.414 & $<0.0001$ & -0.427 & 43 & 0.0034 \\
\hline $2-3$ & 0.260 & 0.0004 & -0.113 & 43 & 0.4595 & 0.386 & $<0.0001$ & -0.160 & 43 & 0.2948 \\
\hline $1-4$ & 0.284 & 0.0002 & 0.061 & 43 & 0.693 & 0.271 & 0.0002 & -0.179 & 43 & 0.24 \\
\hline $2-6$ & 0.202 & 0.002 & 0.226 & 43 & 0.135 & 0.244 & 0.0006 & 0.135 & 43 & 0.3757 \\
\hline $9-16$ & 0.321 & $<0.0001$ & 0.459 & 43 & 0.0015 & 0.261 & 0.0003 & 0.183 & 43 & 0.2279 \\
\hline $16-8$ & 0.236 & 0.0007 & 0.606 & 43 & $<0.0001$ & 0.228 & 0.0009 & 0.339 & 43 & 0.0227 \\
\hline $9-8$ & 0.218 & 0.0012 & 0.622 & 43 & $<0.0001$ & 0.222 & 0.0011 & 0.692 & 43 & $<0.0001$ \\
\hline $1-\mathrm{A}$ & 0.358 & $<0.0001$ & -0.160 & 43 & 0.2954 & 0.456 & $<0.0001$ & 0.084 & 43 & 0.5826 \\
\hline $1-B$ & 0.222 & 0.0011 & 0.673 & 43 & $<0.0001$ & 0.254 & 0.0004 & 0.645 & 43 & $<0.0001$ \\
\hline $1-X$ & 0.126 & 0.0166 & 0.777 & 43 & $<0.0001$ & 0.215 & 0.0014 & 0.742 & 43 & $<0.0001$ \\
\hline$X-Y$ & 0.045 & 0.1599 & & & & 0.051 & 0.1361 & & & \\
\hline$Y-4$ & 0.000 & 0.957 & & & & 0.030 & 0.2557 & & & \\
\hline \multicolumn{11}{|c|}{ Medium river } \\
\hline $1-2$ & 0.252 & 0.0565 & & & & 0.282 & 0.0417 & 0.114 & 13 & 0.6848 \\
\hline $2-3$ & 0.111 & 0.2249 & & & & 0.138 & 0.1728 & & & \\
\hline $1-4$ & 0.199 & 0.0953 & & & & 0.266 & 0.0489 & 0.141 & 13 & 0.6169 \\
\hline $2-6$ & 0.185 & 0.1095 & & & & 0.243 & 0.0621 & & & \\
\hline $9-16$ & 0.054 & 0.4035 & & & & 0.112 & 0.2226 & & & \\
\hline $16-8$ & 0.101 & 0.2481 & & & & 0.073 & 0.3317 & & & \\
\hline $9-8$ & 0.119 & 0.208 & & & & 0.160 & 0.1396 & & & \\
\hline $1-\mathrm{A}$ & 0.098 & 0.2561 & & & & 0.069 & 0.3434 & & & \\
\hline 1-B & 0.051 & 0.4182 & & & & 0.094 & 0.2673 & & & \\
\hline $1-X$ & 0.000 & 0.9522 & & & & 0.001 & 0.9068 & & & \\
\hline$X-Y$ & 0.048 & 0.4337 & & & & 0.069 & 0.3462 & & & \\
\hline Y-4 & 0.017 & 0.6441 & & & & 0.094 & 0.2667 & & & \\
\hline
\end{tabular}


The specimens reared from medial rivers showed allometry only for two features (1-4 and 2-3) on the hind wing.

Consequently, the following statements apply to only four watercourse types (excluding medial rivers): (1) features 1-4 were isoallometric in 3 types and hyperallometric in little rivers on both wings; (2) features 1-2, 2-3 and 2-6 were mostly isoallometric, but in some cases hyperallometry or no allometry; (3) the 9-16, 9-8 and features 8-16 were mostly hyperallometric on both wings, but features of the fore wing in brooks showed no allometry and features 9-16 of the hind wing in little river showed isometry; (4) features 1-A, 1-B and 1-X were mostly hyperallometric, except that 1-A showed isoallometry in creeks and little rivers on both wings and in brooks on the fore wing, 1-B showed no allometry in creeks on the fore wing, 1-X showed no allometry in creeks on both wings; (5) features X-Y showed no allometry except in creeks on the fore wing and streams on the hind wing where these were hyperallometric. The feature Y-4 was not allometric.

\section{DISCUSSION}

Morphological studies, especially traditional morphometrics (as is the case in this work), have been used for a very long time. Nevertheless, these studies are used for solving taxonomic problems, population characterisations and comparisons. However, although some work deals with differences between populations (Outomuro et al. 2013, TAYlor \& Merriam 1995), we have very little information about adult morphometric differences among watercourse types.

Hardersen (2010) and Gallesi et al. (2016) have found that the season affects the morphology and shape of the wing of $C$. splendens.

Other studies showed differences in body length, wing size, wing shape and wing spot size between different populations (e.g. Mertens et al. 1992, Outomuro et al. 2013, SADEGHi et al. 2009). Many factors affect body size in the case of amphibious taxa, especially temperature and quantity of food (McKIE \& Cranston 2005, Shingleton et al. 2007). Larger body size refers to better environmental circumstances in the larval stage (TeDer et al. 2008). The large amount of food consumed during the larval stage resulted in larger adult body sizes (MARDEN 1989) and may allow individuals to store a larger volume of fat reserves (MARDEN 1989). This may mean an adaptive shift in the immature stage (Plaistow \& Siva-Jothy 1999). These works also suggest that there may be differences in the body size of adults among biotopes.

In contrast, we have found no significant differences in mean body sizes among watercourse types. Nonetheless, mean body sizes were larger in creeks and medial rivers than in the other three types, and the differences were not significant. This may indicate that the food supply in the studied types is evenly good. However, the data also show that larger individuals 
are present with a higher frequency in little and medial rivers. There are two possible reasons for this: (i) competition for food which affects selection to larger body size (Blomevist et al. 1997) or (ii) there is a high probability of cannibalism, such that larvae can fall victim (CROwley \& Hopper 1994) and their density can significantly decrease (VAN BUSKIRK 1989). Therefore, cannibalism can raise the ratio of large body size and reduce the proportion of small specimens. In some cases, small individuals may be missing.

The environmental circumstances can affect the size, shape and ornamental traits of damselflies wings (RüppeLl et al. 2005). The size and shape of the wing can significantly affect flight performance. Longer wings can increase flight speed, while wider wings can increase the ability to turn quickly (Hedenström \& Rosén 2001). It is known that predation can often cause strong selection and rapid evolutionary change in natural populations (ТномрsоN 1998). Svensson and Friberg (2007) found that predation means a selection pressure for shorter and wider wings in Calopteryx splendens.

Gallesi et al. (2016) pointed out that the wing shape shows a seasonal variation and the different mating tactics associated with different wing morphologies in both sexes of $C$. splendens. In addition, a positive correlation has also been proved between habitat heterogeneity and morphological traits related to flight (RofF 1990, TaYlor \& Merriam 1995).

In contrast to body sizes, we found significant differences in most of the wing features between individuals reared from different water body types. The differences were significant for all of the size-related features, but only features 1-A (the distance between the wing base and the wing spot's proximal edge on the fore-section of costa) and 1-B (the distance between the wing base and the wing spot's proximal edge on the back-section of costa) were related to the size and shape of the spot.

Outomuro et al. (2012) found a higher evolutionary divergence of hind wing shape in both sexes of $C$. splendens. We found that the number of significant differences detected by post hoc tests was greater in the fore wing (36) than in the hind (25) wing. Our results also suggest that individuals reared from the creeks and medial rivers are different from the others in most features. This can also be explained by the fact that these two types have the lowest flow rate, which may be disad vantageous for larvae (GibBOns \& PAIN 1992, Siva-Jотну et al. 1995). In contrast, individuals reared from brooks, streams, and little rivers are very similar, with no significant differences in any feature (hind wing) or only in one feature (fore wing).

The PCAs also support these results since the biplot displays different features in different degrees on the two wings distinguishing the watercourse types.

If the two wings and the water body types are examined together, a similarity can be determined between the individuals reared from brooks and streams, while the spot clouds of the fore and hind wings completely overlap. 
In contrast, there are significant differences between the two wings for those reared from streams, medial or little rivers, especially little rivers.

It is known that environmental circumstances affect allometric patterns (Battán Horenstein \& Peretti 2011) and stability of development (Palmer \& SтRовеск 1992, Sото et al. 2008) in larval stages. This can explain our result, which shows that the number and proportion of allometric traits also vary among different watercourse types. This is especially significant if we consider hyperallometric traits. The ratio of allometric features was highest in the individuals reared from creeks, streams and little rivers and did not differ or differed only insignificantly between the two wings. In contrast, the proportion of non-allometric features on the fore wing is very high for those reared from brooks. From this viewpoint, the individuals reared from medial rivers differed most from the others, while the features on the fore wing were not allometric at all, and only two features showed isoallometry on the hind wing.

Outomuro and Cordero-Rivera (2012) pointed out that wing pigmentation traits of males in species of the family Calopterygidae are hyperallometric. By contrast, studies support that this is not universal (BonDURIANSKY 2007, Outomuro et al. 2014). We found that wing spot related features were hyperallometric in most cases, but can be isoallometric or non-allometric in some water body types.

We assume that in favourable habitats, the development of wing traits is under strong allometric regulation. This regulation is weaker if the habitat is less favourable for larvae. Thus, differences in larval habitat could result in significant variation of adults. Our work shows that morphometric characteristics and allometric patterns can characterise individuals developed in different ecological watercourse types.

Author contributions - collected the specimens: M.M., D.Gy., performed the measurements: SZ.P.É., K.O., data curation: Sz.L.J., writing-original: Sz.L.J., D.Gy., V.Cs., writing-review and editing: Sz.L.J., D.Gy., V.Cs.

Acknowledgements - The authors are very much obliged to the reviewers for their thorough and precise work. Furthermore, the authors would like to thank associate professor Dr. habil. Péter Pelyvás (Department of English Linguistics, University of Debrecen) for the linguistic corrections of the manuscript. The research of Olga Kis and Petra Éva Szalay was supported by the European Union and the State of Hungary, co-financed by the European Social Fund in the framework of [TÁMOP 4.2.4.A/2-11-1-2012-0001] "National Excellence Program".

\section{REFERENCES}

АмвӥнL, H. (1959): Die Bedeutung der Strömung als ökologischer Faktor. - Schweizerische Zeitschrift für Hydrologie 21(2): 133-264. https://doi.org/10.1007/BF02505455 
Battán Horenstein, M. \& Peretti, A. V. (2011): Environmental conditions influence allometric patterns in the blow fly, Chrysomya albiceps. - Journal of Insect Science (Online) 11(131): 1-10. https://doi.org/10.1673/031.011.13101

Bernáth, B., Szedenics, G., Wildermuth, H. \& Horváth, G. (2002): How can dragonflies discern bright and dark waters from a distance? The degree of polarisation of reflected light as a possible cue for dragonfly habitat selection. - Freshwater Biology 47: 1707-1719. https://doi.org/10.1046/j.1365-2427.2002.00931.x

Blomqvist, D., Johansson, O. C., Unger, U. N. O., Larsson, M. \& Flodin, L.-Å. (1997): Male aerial display and reversed sexual size dimorphism in the dunlin. - Animal Behaviour 54(5): 1291-1299. https://doi.org/10.1006/anbe.1997.0532

BONDURIANSKY, R. (2007): Sexual selection and allometry: a critical reappraisal of evidence and ideas. - Evolution 61(4): 838-849. https://doi.org/10.1111/j.1558-5646.2007.00081.x

CAmpBell, I. C. (1991): Size allometry in some Australian mayfly nymphs (Insecta: Ephemeroptera). - Aquatic Insects 13(2): 79-86. https://doi.org/10.1080/01650429109361427

Chaput-Bardy, A., Gregoire, A., Baguette, M., Pagano, A. \& Secondi, J. (2010): Condition and phenotype-dependent dispersal in a damselfly, Calopteryx splendens. - PLoS ONE 5(5): e10694. https://doi.org/10.1371/journal.pone.0010694

Corbet, P. S. (1999): Dragonflies: behavior and ecology of Odonata. - Harley, Colchester, 829 pp.

Crowley, P. H. \& Hopper, K. R. (1994): How to behave around cannibals: a density-dependent dynamic game. - The American Naturalist 143(1): 117-154. https://doi.org/10.1086/285598

D’ Amico, F., Darblade, S., Avignon, S., Blanc-Manel, S. \& Ormerod, S. (2004): Odonates as indicators of shallow lake restoration by liming: comparing adult and larval responses. - Restoration Ecology 12: 439-446. https://doi.org/10.1111/j.1061-2971.2004.00319.x

DévaI, Gr. (1976): Proposal for the classification of inland (continental) waters. - Acta Biologica Debrecina 13: 147-161.

Dévai, Gy., Nagy, S., Wittner, I., Aradi, C., Csabai, Z. \& Tóth, A. (2001): Specific features and typology of aquatic and semiaquatic biotopes. Pp. 11-74. In: BöHM, A. \& SzABó, M. (eds): Wetlands: interface between natural and social environment. - ELTE-TTK, SZIEKGI \& KöM-TvH, Budapest.

Dmitriew, C., Cooray, M. \& Rowe, L. (2007): Effects of early resource-limiting conditions on patterns of growth, growth efficiency, and immune function at emergence in a damselfly (Odonata: Coenagrionidae). - Canadian Journal of Zoology 85(3): 310-318. https://doi.org/10.1139/z07-004

Dubois, E. (1897): Sur le rapport de l'encephale avec la grandeur du corps chez les Mammiferes. - Bulletin of Social Anthropology 8: 337-374. https://doi.org/10.3406/bmsap.1897.5705

Dumont, H. J. (1991): Odonata of the Levant. - Israel Academy of Sciences and Humanities, Jerusalem, VIII + 304 pp.

Gallesi, M. M., Mobili, S., Cigognini, R., Hardersen, S. \& Sacchi, R. (2016): Season matters: differential variation of wing shape between sexes of Calopteryx splendens (Odonata: Calopterygidae). - Zoomorphology 135(3): 313-322. https://doi.org/10.1007/s00435-016-0309-8

Gibbons, D. W. \& Pain, D. (1992): The influence of river flow rate on the breeding behaviour of Calopteryx damselflies. - Journal of Animal Ecology 61(2): 283-289.

https://doi.org/10.2307/5321

Goodyear, K. G. (2000): A comparison of the environmental requirements of larvae of the Banded Demoiselle Calopteryx splendens (Harris) and the Beautiful Demoiselle C. virgo (L.). - Journal of the British Dragonfly Society 16(2): 33-51. 
Hammer, Ø., Harper, D. A. T. \& Ryan, P. D. (2001): Paleontological statistics software package for education and data analysis. - Paleontologia Electronica 4(1): 1-9.

HARDERSEN, S. (2010): Seasonal variation of wing spot allometry in Calopteryx splendens (Odonata Calopterygidae). - Ethology Ecology E Evolution 22(4): 365-373. https://doi.org/10.1080/03949370.2010.510042

Hassall, C. \& Thompson, D. (2008): The impacts of environmental warming on Odonata: a review. - International Journal of Odonatology 11(2): 131-153. https://doi.org/10.1080/13887890.2008.9748319

Hedenström, A. \& Rosén, M. (2001): Predator versus prey: on aerial hunting and escape strategies in birds. - Behavioral Ecology 12(2): 150-156.

https://doi.org/10.1093/beheco/12.2.150

Horenstein, M. B., Linhares, A. X., De Ferradas, B. R. \& García, D. (2010): Decomposition and dipteran succession in pig carrion in central Argentina: ecological aspects and their importance in forensic science. - Medical and Veterinary Entomology 24(1): 16-25. https://doi.org/10.1111/j.1365-2915.2009.00854.x

HuXLEY, J. S. (1924): Constant differential growth-ratios and their significance. - Nature 114: 895-896. https://doi.org/10.1038/114895a0

Jajuga, K. \& WALESIAK, M. (2000): Standardisation of data set under different measurement scales. Pp. 105-112. In: Decker, R. \& Gaul, W. (eds): Classification and information processing at the turn of the Millennium. - Springer, Berlin, Heidelberg. https://doi.org/10.1007/978-3-642-57280-7_11

Klingenberg, C. P. \& Zimmermann, M. (1992): Static, ontogenetic, and evolutionary allometry: a multivariate comparison in nine species of water striders. - The American Naturalist 140(4): 601-620. https://doi.org/10.1086/285430

Lajter, I., Móra, A., Grigorszki, I., Nagy, S. \& Dévai, Gy. (2010): Characterisation of the Hungarian section of River Tisza and its major tributaries near their confluences to the mainstream on the basis of aquatic macroinvertebrate communities. - Studia Odonatologica Hungarica Supplementum 1: 9-122.

MARDEN, J. H. (1989): Bodybuilding dragonflies: costs and benefits of maximising flight muscle. - Physiological Zoology 62(2): 505-521. https://doi.org/10.1086/physzool.62.2.30156182

McKie, B. G. \& Cranston, P. S. (2005): Size matters: systematic and ecological implications of allometry in the responses of chironomid midge morphological ratios to experimental temperature manipulations. - Canadian Journal of Zoology 83(4): 553-568. https://doi.org/10.1139/z05-051

McLelland, S. J., Ashworth, P. J. \& Best, J. L. (1996): The origin and downstream development of coherent flow structures at channel junctions. Pp. 459-490. In: Asнworth, P. J., Best, J. L. \& McLelland, S. J. (eds): Coherent flow structures in open channels. - John Wiley and Sons Ltd., Hoboken.

Mertens, J., De Coster, W., De Meyer, H. \& Dumont, H. J. (1992): A method for the quantitative analysis of wing spot applied to two populations of Calopteryx splendens (Harris) (Zygoptera: Calopterygidae). - Odonatologica 21(4): 443-451.

Mikolajewski, D. J., Brodin, T., Johansson, F. \& Joop, G. (2005): Phenotypic plasticity in gender specific life-history: effects of food availability and predation. - Oikos 110(1): 91-100. https://doi.org/10.1111/j.0030-1299.2005.13766.x

Minot, M., Le Gall, M. \& Huste, A. (2019): Biometry of the large dragonfly Anax imperator (Odonata: Aeshnidae): A study of traits from larval development to adults. - European Journal of Entomology 116(1): 269-280. https://doi.org/10.14411/eje.2019.031

Naiman, R. J., Bilby, R. E., Schindler, D. E. \& Helfield, J. M. (2002): Pacific salmon, nutrients, and the dynamics of freshwater and riparian ecosystems. - Ecosystems 5(4): 399-417. https://doi.org/10.1007/s10021-001-0083-3 
Outomuro, D., Boкma, F. \& Johansson, F. (2012): Hind wing shape evolves faster than front wing shape in Calopteryx damselflies. - Evolutionary Biology 39(1): 116-125. https://doi.org/10.1007/s11692-011-9145-4

Outomuro, D. \& Cordero-Rivera, A. (2012): Allometry of secondary, primary, and nonsexual traits in the beautiful demoiselle (Calopteryx virgo meridionalis). - Canadian Journal of Zoology 90(9): 1094-1101. https://doi.org/10.1139/z2012-076

Outomuro, D., Cordero Rivera, A., Nava-Bolaños, A. \& Córdoba-Aguilar, A. (2014): Does allometry of a sexually selected ornamental trait vary with sexual selection intensity? A multi-species test in damselflies. - Ecological Entomology 39(3): 399-403. https://doi.org/10.1111/een.12098

Outomuro, D., Dijkstra, K. D. \& Johansson, F. (2013): Habitat variation and wing coloration affect wing shape evolution in dragonflies. - Journal of Evolutionary Biology 26(9): 1866-1874. https://doi.org/10.1111/jeb.12203

PAlmer, A. R. \& Strobeck, C. (1992): Fluctuating asymmetry as a measure of developmental stability: Implications of non-normal distributions and power of statistical tests. - Acta Zoologica Fennica 191: 57-72.

Petts, G. E. (2000): A perspective on the abiotic processes sustaining the ecological integrity of running waters. - Hydrobiologia 422: 15-27.

https://doi.org/10.1023/A:1017062032685

Plaistow, S. \& Siva-Jothy, M. T. (1999): The ontogenetic switch between odonate life history stages: effects on fitness when time and food are limited. - Animal Behaviour 58(3): 659-667. https://doi.org/10.1006/anbe.1999.1171

R Core TeAm (2018): R: A language and environment for statistical computing. - R Foundation for Statistical Computing, Vienna.

Roff, D. A. (1990): The evolution of flightlessness in insects. - Ecological Monographs 60(4): 389-421. https://doi.org/10.2307/1943013

Rüppell, G., Hilfert-Rüppell, D., Rehfeldt, G. \& Schütte, C. (2005): Die Prachtlibellen Europas. Gattung Calopteryx. Die Neue Brehm-Bücherei Bd. 654. - Westarp WissenschaftenVerlagsgesellschaft $\mathrm{GmbH}$, Hohenwarsleben.

SACChI, R. \& HARdersen, S. (2012): Wing length allometry in Odonata: differences between families in relation to migratory behaviour. - Zoomorphology 132(1): 23-32. https://doi.org/10.1007/s00435-012-0172-1

Sadeghi, S., Adriaens, D. \& Dumont, H. J. (2009): Geometric morphometric analysis of wing shape variation in ten European populations of Calopterys splendens (Harris, 1782) (Zygoptera: Calopterygidae). - Odonatologica 38(4): 341-357.

Schlichting, C. \& Pigliucci, M. (1998): Phenotypic evolution: A reaction norm perspective. Sinauer Associates Inc, Sunderland, Massachusetts, 387 pp.

SHeA, B. T. (1985): Bivariate and multivariate growth allometry: statistical and biological considerations. - Journal of Zoology 206(3): 367-390. https://doi.org/10.1111/j.1469-7998.1985.tb05665.x

Shingleton, A. W., Frankino, W. A., Flatt, T., Nijhout, H. F. \& Emlen, D. J. (2007): Size and shape: the developmental regulation of static allometry in insects. - Bioessays 29(6): 536-48. https://doi.org/10.1002/bies.20584

Siva-Jothy, M. T., Gibbons, D. \& PAIN, D. (1995): Female oviposition-site preference and egg hatching success in the damselfly Calopteryx splendens xanthostoma. - Behavioral Ecology and Sociobiology 37: 39-44. https://doi.org/10.1007/BF00173897

Soto, I. M., Carreira, V. P., Soto, E. M. \& Hasson, E. (2008): Wing morphology and fluctuating asymmetry depend on the host plant in cactophilic Drosophila. - Journal of Evolutionary Biology 21(2): 598-609. https://doi.org/10.1111/j.1420-9101.2007.01474.x 
Stern, D. L. \& Emlen, D. J. (1999): The developmental basis for allometry in insects. - Development 126(6): 1091-1101. https://doi.org/10.1242/dev.126.6.1091

StetTmer, C. (1996): Colonisation and dispersal patterns of banded (Calopteryx splendens) and beautiful demoiselles (C. virgo) in south-east German streams. - European Journal of Entomology 93: 579-593.

Stewart, S. \& Vodopich, D. (2018): Environmental effects on wing shape and wing size of Argia sedula (Odonata: Coenagrionidae). - International Journal of Odonatology 21: 1-15. https://doi.org/10.1080/13887890.2018.1523752

Stewart, T. W. \& Downing, J. A. (2008): Macroinvertebrate communities and environmental conditions in recently constructed wetlands. - Wetlands 28(1): 141-150. https://doi.org/10.1672/06-130.1

Svensson, E. I. \& Friberg, M. (2007): Selective predation on wing morphology in sympatric damselflies. - The American Naturalist 170(1): 101-112. https://doi.org/10.1086/518181

Svensson, E. I., Kristoffersen, L., Oskarsson, K. \& Bensch, S. (2004): Molecular population divergence and sexual selection on morphology in the banded demoiselle (Calopteryx splendens). - Heredity 93(5): 423-433. https://doi.org/10.1038/sj.hdy.6800519

TAylor, P. D. \& Merriam, G. (1995): Wing morphology of a forest damselfly is related to landscape structure. - Oikos 73(1): 43-48. https://doi.org/10.2307/3545723

Teder, T., Tammaru, T. \& Esperk, T. (2008): Dependence of phenotypic variance in body size on environmental quality. - The American Naturalist 172(2): 223-232. https://doi.org/10.1086/589896

Thompson, J. N. (1998): Rapid evolution as an ecological process. - Trends in Ecology E Evolution 13(8): 329-332. https://doi.org/10.1016/S0169-5347(98)01378-0

VAN Buskirk, J. (1989): Density-dependent cannibalism in larval dragonflies. - Ecology 70(5): 1442-1449. https://doi.org/10.2307/1938203

WARD, L. \& MiLl, P. (2007): Long range movements by individuals as a vehicle for range expansion in Calopteryx splendens (Odonata: Zygoptera). - European Journal of Entomology 104(2): 195-198. https://doi.org/10.14411/eje.2007.030

Ward, L. \& Mill, P. J. (2005): Habitat factors influencing the presence of adult Calopteryx splendens (Odonata: Zygoptera). - European Journal of Entomology 102(1): 47-51. https://doi.org/10.14411/eje.2005.007

Warton, D. I., Duursma, R. A., Falster, D. S. \& Taskinen, S. (2012): smatr 3 - an R package for estimation and inference about allometric lines. - Methods in Ecology and Evolution 3(2): 257-259. https://doi.org/10.1111/j.2041-210X.2011.00153.x

Warton, D. I., Wright, I. J., Falster, D. S. \& Westoby, M. (2006): Bivariate line-fitting methods for allometry. - Biological Reviews 81(2): 259-291. https://doi.org/10.1017/S1464793106007007

Williams, C. M. (1980): Growth in insects. Pp. 369-383. In: Locke, M. (ed.): Insect biology in the future. - Academic Press, London. https://doi.org/10.1016/B978-0-12-454340-9.50022-7

Zahner, R. (1959): Über die Bindung der mitteleuropäischen Calopteryx-Arten (Odonata, Zygoptera) an den Lebensraum des strömenden Wassers. - Internationale Revue der gesamten Hydrobiologie und Hydrographie 44(1-4): 51-130.

https://doi.org/10.1002/iroh.19590440105

Received February 22, 2021, accepted November 12, 2021, published February 14, 2022 